\title{
Pyruvic Acid Production from 1,2-Propanediol by Thiamin-requiring Acinetobacter sp. 80-M
}

\author{
Yoshikazu IzUmi, Yoshiaki Matsumura, Yoshiki TaNI \\ and Hideaki YAMADA \\ Department of Agricultural Chemistry, Kyoto University, \\ Kyoto 606, Japan
}

Received December 25, 1981

\begin{abstract}
For the purpose of producing pyruvic acid from 1,2-propanediol (PD), three PD-utilizing and thiamin-requiring microorganisms were isolated from soil. All the isolated strains were found to be pyruvic acid producers. Among them, strain $80-\mathrm{M}$ was the best producer and was identified as an Acinetobacter sp. With this bacterium, the conditions were optimized for pyruvic acid production from PD by two methods: growing cell and resting cell methods. The amount of thiamin added to the medium remarkably affected the pyruvic acid production using either method. Under optimal conditions, 14.6 and $10.0 \mathrm{mg} / \mathrm{ml}$ of pyruvate as a sodium salt were produced from $20 \mathrm{mg} / \mathrm{ml}$ of PD by the growing and resting cell methods, respectively. In the resting cell system, only PD-grown cells showed a significant pyruvate productivity from PD.
\end{abstract}

There have been some reports on the microbial production of pyruvic acid from glucose, ${ }^{1 \sim 3)}$ gluconate, ${ }^{4)}$ lactate ${ }^{5)}$ and 1,2-propanediol (PD). ${ }^{6)}$ However, the amounts of pyruvic acid accumulated were unsatisfactory.

Only a few studies have used thiaminrequiring microorganisms, which produce pyruvic acid when cultivated in the presence of thiamin at a low concentration. ${ }^{2,4)}$ The cause of this pyruvate accumulation is most likely that thiamin diphosphate-dependent pyruvate dehydrogenase, responsible for pyruvate degradation, hardly functions owing to the coenzyme deficiency. Therefore, we considered that there might be thiaminrequiring microorganisms having high pyruvic acid productivity, and tried to isolate such organisms from natural sources. In the present work, we choose PD as a raw material for puruvic acid production since the compound, an alcohol having the same carbon number as pyruvic acid, is one of the cheap petrochemicals.

The present paper deals with the isolation and identification of a PD-utilizing and thiamin-requiring bacterium which produced large amounts of pyruvic acid from PD, and the optimization of the conditions for pyruvic acid production by two different methods, i.e., a growing cell method and resting cell method, using the bacterium.

\section{MATERIALS AND METHODS}

Organisms. PD-utilizing and thiamin-requiring microorganisms were isolated from soil samples in Kyoto.

Chemicals. Kongo-amino-san ${ }^{\circledR}$ was the kind gift of Ajinomoto Co., Inc., Japan. Other chemicals were commercial products of reagent grade.

Media. The following media were used during this work. Medium P-I: $20 \mathrm{~g}$ PD, $3 \mathrm{~g} \mathrm{NH}_{4} \mathrm{NO}_{3}, 2 \mathrm{~g} \mathrm{~K}_{2} \mathrm{HPO}_{4}, 1 \mathrm{~g} \mathrm{KCl}$, $0.2 \mathrm{~g} \mathrm{MgSO}_{4} \cdot 7 \mathrm{H}_{2} \mathrm{O}, 10 \mathrm{mg} \mathrm{FeSO}{ }_{4} \cdot 7 \mathrm{H}_{2} \mathrm{O}, 10 \mathrm{mg} \mathrm{MnSO}_{4} \cdot$ $4 \sim 6 \mathrm{H}_{2} \mathrm{O}, 20 \mathrm{~g} \mathrm{CaCO}_{3}$ (precipitated) and $10 \mu \mathrm{g}$ thiamin. $\mathrm{HCl}$ in 1 liter of distilled water, $\mathrm{pH}$ 7.0. Medium P-II: $3 \mathrm{~g}$ Polypepton (Daigo) replaced $\mathrm{NH}_{4} \mathrm{NO}_{3}$ in medium P-I. Medium G: $20 \mathrm{~g}$ glucose replaced PD in medium P-II and $\mathrm{CaCO}_{3}$ was omitted. For a slant-culture medium $2 \%$ agar was added, and for a plate-culture medium $2 \%$ agar was added and $\mathrm{CaCO}_{3}$ omitted. $\mathrm{CaCO}_{3}$ was separately sterilized by dry heating. For the preservation of strains a slant-culture medium of medium $G$ was used.

Isolation of $P D$-utilizing, thiamin-requiring organisms. Soil samples were cultivated with shaking at $28^{\circ} \mathrm{C}$ for 2 days in $5 \mathrm{ml}$ of medium P-I. The cultured broth was 
streaked on a plate of medium P-I and cultivated at $28^{\circ} \mathrm{C}$ for $3 \sim 4$ days. The colonies were transferred to two different plates of medium P-I with and without thiamin. The strains, which grew only on the plate of the medium with thiamin, were transferred to slants of medium $\mathrm{G}$ and cultivated at $28^{\circ} \mathrm{C}$ for $2 \sim 3$ days.

Cultivation for pyruvate production. Organisms were precultured in $5 \mathrm{ml}$ of medium P-I or P-II at $28^{\circ} \mathrm{C}$ for 1 day with shaking $(350 \mathrm{rpm})$. The precultured broth $(1 \%(\mathrm{v} / \mathrm{v})$ of main culture medium) was inoculated into the main culture medium. Cultivation was carried out at $28^{\circ} \mathrm{C}$ for 4 days with reciprocal shaking $(350 \mathrm{rpm}$ for test tubes and $120 \mathrm{rpm}$ for flasks).

Preparation of resting cells of strain $80-M$. The organism was precultured at $28^{\circ} \mathrm{C}$ for 1 day in $5 \mathrm{ml}$ of medium P-II containing $0.5 \%$ instead of $0.3 \%$ Polypepton. The whole precultured broth was transferred to a 500-ml shaking falsk containing $100 \mathrm{ml}$ of the same medium and cultivated at $28^{\circ} \mathrm{C}$ for 2 days with shaking. The cultured broth was centrifuged at $800 \times g$ for $5 \mathrm{~min}$ at $0^{\circ} \mathrm{C}$ to remove $\mathrm{CaCO}_{3}$ and then the supernatant was centrifuged at $10,000 \times g$ for $10 \mathrm{~min}$ at $0^{\circ} \mathrm{C}$. The cells harvested were washed once with $0.85 \% \mathrm{NaCl}$ solution, and suspended in the $\mathrm{NaCl}$ solution. The cell suspension, which was frozen at $-20^{\circ} \mathrm{C}$ until use, was employed for resting cell reactions. One unit of $\mathrm{OD}_{610}$ of the suspension corresponded to $0.267 \mathrm{mg}$ (as dry weight $) / \mathrm{ml}$ of cells.

Pyruvate production of resting cells. The standard reaction mixture contained $200 \mathrm{mg} \mathrm{PD}, 200 \mathrm{mg} \mathrm{CaCO}_{3}$ (precipitated), $1 \mathrm{mmol}$ potassium phosphate buffer ( $\mathrm{pH}$ 7.0 ) and $26 \mathrm{mg}$ (as dry weight) cells in a total volume of $10 \mathrm{ml}$ in a $24-\mathrm{mm} \phi$ test tube. The reaction was performed at $28^{\circ} \mathrm{C}$ for $24 \mathrm{hr}$ with reciprocal shaking $(350 \mathrm{rpm})$.

Determination of pyruvic acid. Pyruvic acid produced in the cultured broth or reaction mixture was determined by the method of Friedemann and Haugen, ${ }^{7}$ with sodium pyruvate as the standard.

Determination of growth. After $2 \mathrm{~N} \mathrm{HCl}$ was added to the cultured broth to dissolve $\mathrm{CaCO}_{3}(2 \mathrm{ml}$ of the acid against $0.1 \mathrm{~g} \mathrm{CaCO}_{3}$ ), the optical density was measured at $610 \mathrm{~nm}$.

\section{RESULTS}

\section{Isolation of PD-utilizing and thiamin-requiring microorganisms}

From about 300 PD-utilizing isolates from soil, three strains were found to require thiamin for growth. The strains were tested for pyruvic acid production in medium P-I. As a result, all three strains were found to produce
Table I. TaXonomical Studies of STRAIN 80-M

Morphological characteristics

Shape and size of cells: rods, $0.73 \sim 0.81 \times 1.5 \sim 3.7 \mu \mathrm{m}$, predominantly in pairs

Motility: non-motile

Spores: not formed

Gram stain: negative

Aminopeptidase reaction*: positive

Cultural characteristics

Colonies on nutrient agar: white to pale orange, non-chromogenic, circular, smooth convex, and glistening

Liquefaction of gelatin: negative

Physiological characteristics

Aerobic growth: strictly aerobic

Reduction of nitrate: positive

VP test: negative

MR test: negative

Indole production: negative

Hydrogen sulfide production: negative

Hydrolysis of starch: negative

Urease reaction: positive

Oxidase reaction: negative

Catalase reaction: positive

Litmus milk: positive

Temperature for growth: $5 \sim 40^{\circ} \mathrm{C}$; $\mathrm{pH}$ for growth: $5.5 \sim 9.0$

Penicillin resistance: resistant to 10 units $/ \mathrm{ml}$ of penicillin

Requirements for growth: thiamin

OF test: negative

Acid formation from carbohydrates: Acid was formed from galactose, mannose and dextrin.

* See ref. 8.

100 to $600 \mu \mathrm{g} / \mathrm{ml}$ of a sodium salt. From these, strain $80-\mathrm{M}$, the best producer, was used for the following experiments after improving the productivity by mono-colony screening.

\section{Identification of strain $80-M$}

The results of taxonomical studies of strain $80-\mathrm{M}$ are summarized in Table I. From these results, we concluded that strain $80-\mathrm{M}$ belongs to the genus Acinetobacter according to Bergey's Manual, 8th Ed.9)

Culture conditions for pyruvate production from $P D$ by strain $80-M$

To improve the pyruvate production from PD by strain $80-\mathrm{M}$, the following culture 


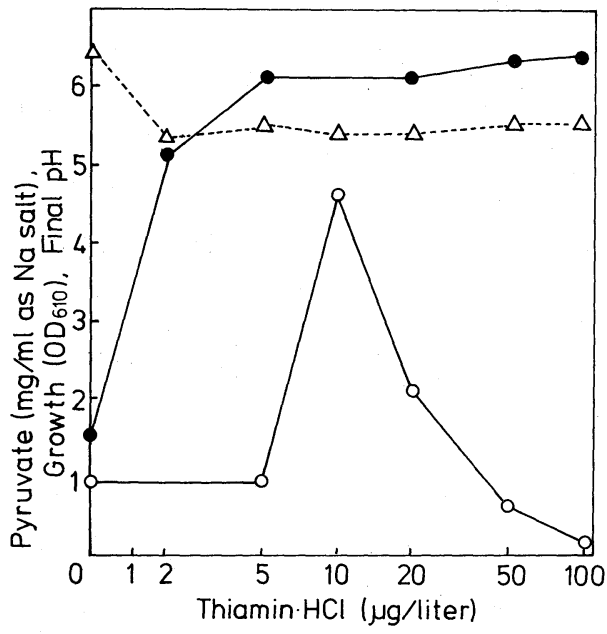

FIG. 1. Effect of Thiamin on the Growth of Strain 80-M and Its Pyruvate Production from PD.

The organism was cultivated at $28^{\circ} \mathrm{C}$ for 4 days in a 24 $\mathrm{mm} \phi$ test tube containing $10 \mathrm{ml}$ of medium P-II, where the thiamin $\cdot \mathrm{HCl}$ concentration was varied as indicated. growth; $\bigcirc$, pyruvate produced; $\triangle, \mathrm{pH}$.

Table II. EFFect of Nitrogen Source on the Pyruvate Production

The organism was cultivated at $28^{\circ} \mathrm{C}$ for 3 days in a $500-\mathrm{ml}$ flask containing $100 \mathrm{ml}$ of medium P-I.

\begin{tabular}{lll}
$\begin{array}{c}\text { Nitrogen source } \\
(0.3 \%)\end{array}$ & $\begin{array}{c}\text { Growth } \\
\left(\mathrm{OD}_{610}\right)\end{array}$ & $\begin{array}{c}\text { Pyruvate } \\
(\mathrm{mg} / \mathrm{ml} \text { as } \\
\mathrm{Na} \text { salt })\end{array}$ \\
\hline None & 0 & 0 \\
$\mathrm{NH}_{4} \mathrm{NO}_{3}$ & 2.83 & 3.18 \\
$\mathrm{NH}_{4} \mathrm{Cl}$ & 0.83 & 0.13 \\
$\left(\mathrm{NH}_{4}\right)_{2} \mathrm{SO}_{4}$ & 1.05 & 0.13 \\
$\mathrm{NaNO}_{3}$ & 1.35 & 3.11 \\
Urea & 0.33 & 0 \\
Polypepton & 3.25 & 4.66 \\
Casamino acids & 2.13 & 0 \\
Meat extract & 2.72 & 0 \\
Yeast extract & 7.60 & 0 \\
\hline
\end{tabular}

conditions were examined.

(a) Effect of thiamin concentration. As shown in Fig. 1, the growth of strain $80-\mathrm{M}$ increased with increased amounts of thiamin $\cdot \mathrm{HCl}$ up to $5 \mu \mathrm{g} /$ liter, above which there was almost no change in growth. On the other hand, the level of pyruvate was maximal on addition of $10 \mu \mathrm{g} /$ liter of thiamin $\cdot \mathrm{HCl}$; the addition of more than $20 \mu \mathrm{g} /$ liter of

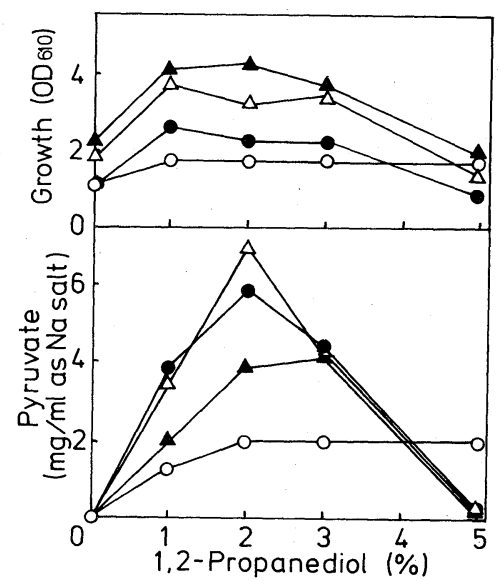

FIG. 2. Effect of PD and Polypepton Concentrations on the Growth and Pyruvate Production.

The PD and Polypepton concentrations of medium P-II were varied as indicated. Other culture conditions were the same as in Fig. 1. Polypepton concentration ( $\%$ ): $\bigcirc, 0.2$; $0.3 ; \triangle, 0.5 ; \boldsymbol{\Delta}, 0.75$.

thiamin $\cdot \mathrm{HCl}$ markedly decreased the pyruvate production.

(b) Effect of $\mathrm{CaCO}_{3}$. The addition of more than $2 \% \mathrm{CaCO}_{3}$ was necessary for the best pyruvate production.

(c) Effect of nitrogen source. Among the nitrogen sources tested as shown in Table II, Polypepton was the most effective for pyruvate production. Nitrates such as $\mathrm{NH}_{4} \mathrm{NO}_{3}$ and $\mathrm{NaNO}_{3}$ were also effective. In the following experiments, Polypepton was used as a nitrogen source.

(d) Effect of PD and Polypepton concentrations. The effect of PD and Polypepton concentrations on the growth and pyruvate production was examined. As shown in Fig. 2, the maximum level of pyruvate was achieved in a medium containing $2 \% \mathrm{PD}$ and $0.75 \%$ Polypepton. The pyruvate production was suppressed when either of the substances was added to a concentration higher than these respective values.

(e) Time course of pyruvate production. Under the optimal conditions obtained in the above experiments, the time course of the pyruvate production was examined. As illustrated in Fig. 3, the growth increased slowly up 


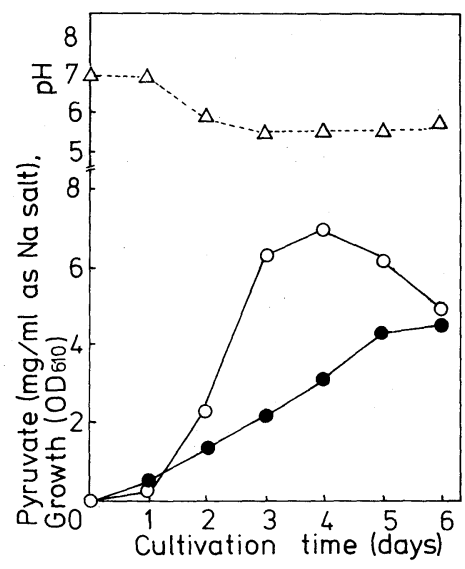

FIG. 3. Time Course of the Pyruvate Production from PD.

The organism was cultivated at $28^{\circ} \mathrm{C}$ in a $24-\mathrm{mm} \phi$ test tube containing $10 \mathrm{ml}$ of medium P-II, where the Polypepton concentration was changed to $0.5 \%$. $\bigcirc$, pyruvate produced; $\triangle, \mathrm{pH}$.

Table III. Effect of Metal Salts on the Pyruvate Production

The organism was cultivated at $28^{\circ} \mathrm{C}$ for 4 days in a $16.5-\mathrm{mm} \phi$ test tube containing $5 \mathrm{ml}$ of medium P-II with $0.5 \%$ instead of $0.3 \%$ Polypepton. Metal salts were added to the medium at concentrations of $10 \mu \mathrm{g} / \mathrm{ml}$.

\begin{tabular}{lcc}
\hline \multicolumn{1}{c}{ Metal salt } & $\begin{array}{c}\text { Growth } \\
\left(\mathrm{OD}_{610}\right)\end{array}$ & $\begin{array}{c}\text { Pyruvate } \\
(\mathrm{mg} / \mathrm{ml} \text { as } \\
\mathrm{Na} \text { salt })\end{array}$ \\
\hline None & 7.00 & 6.85 \\
$\mathrm{CaCl}_{2} \cdot 6 \mathrm{H}_{2} \mathrm{O}$ & 7.20 & 6.63 \\
$\mathrm{ZnSO}_{4} \cdot 7 \mathrm{H}_{2} \mathrm{O}$ & 6.52 & 3.12 \\
$\mathrm{CuSO}_{4} \cdot 5 \mathrm{H}_{2} \mathrm{O}$ & 7.03 & 7.62 \\
$\mathrm{CoCl}_{2} \cdot 6 \mathrm{H}_{2} \mathrm{O}$ & 7.08 & 8.53 \\
$\mathrm{AlCl}_{3} \cdot 6 \mathrm{H}_{2} \mathrm{O}$ & 7.21 & 3.50 \\
$\mathrm{H}_{3} \mathrm{BO}_{3}$ & 7.23 & 6.70 \\
$\mathrm{Na}_{2} \mathrm{MoO}_{4} \cdot 2 \mathrm{H}_{2} \mathrm{O}$ & 7.26 & 7.39 \\
\hline
\end{tabular}

to 5 to 6 days of incubation. The pyruvate production reached its maximum at the late logarithmic phase of growth with a subsequent gradual decrease in pyruvate.

(f) Effect of metal salts. Among the metal salts tested, the addition of $\mathrm{CoCl}_{2}$ increased the pyruvate production by about $25 \%$ (Table III).

(g) Effect of organic nutrients. As indicated in Table IV, Kongo-amino-san, an acidhydrolyzed soybean protein, had a stimulatory
TABle IV. EFFECT OF Organic Nutrients on the Pyruvate Production

The organism was cultivated at $28^{\circ} \mathrm{C}$ for 4 days in a $16.5-\mathrm{mm} \phi$ test tube containing $5 \mathrm{ml}$ of medium P-II with $0.5 \%$ instead of $0.3 \%$ Polypepton. Organic nutrients were added to the medium at concentrations of $1 \mathrm{mg} / \mathrm{ml}$.

\begin{tabular}{lcc}
\hline Organic nutrient & $\begin{array}{c}\text { Growth } \\
\left(\mathrm{OD}_{610}\right)\end{array}$ & $\begin{array}{c}\text { Pyruvate } \\
(\mathrm{mg} / \mathrm{ml} \text { as } \\
\mathrm{Na} \text { salt })\end{array}$ \\
\hline None & 7.82 & 5.79 \\
Corn steep liquor & 8.20 & 0.18 \\
Yeast extract & 26.4 & 0.27 \\
Meat extract & 16.4 & 0.53 \\
Malt extract & 8.83 & 2.67 \\
Casamino acids & 7.64 & 2.04 \\
Kongo-amino-san & 8.40 & 7.79 \\
Cotton seed flour & 8.61 & 0.98 \\
\hline Kongo-amino-san & & \\
$\quad+\mathrm{CoCl}_{2} \cdot 6 \mathrm{H}_{2} \mathrm{O}$ & 8.32 & 14.6 \\
$\left(10 \mu \mathrm{g} / \mathrm{ml}^{2}\right.$ & & \\
\hline
\end{tabular}

effect on pyruvate production, while other nutrients markedly decreased it. When $1 \mathrm{mg} /$ $\mathrm{ml}$ of Kongo-amino-san and $10 \mu \mathrm{g} / \mathrm{ml}$ of $\mathrm{CoCl}_{2} \cdot 6 \mathrm{H}_{2} \mathrm{O}$ were both added to a medium, $14.6 \mathrm{mg} / \mathrm{ml}$ of pyruvate as sodium salt was produced.

\section{Reaction conditions for pyruvate production by resting cells of strain $80-M$}

In a preliminary experiment, resting cells of strain $80-\mathrm{M}$ were also found to produce pyruvate from PD. Therefore, the reaction conditions for the pyruvate production by resting cells were examined.

(a) Effect of thiamin concentration in the culture medium. The effect of the thiamin concentration in the culture medium on the pyruvate productivity of resting cells were examined. As shown in Fig. 4, resting cells grown on $10 \mu \mathrm{g} /$ liter of thiamin $\cdot \mathrm{HCl}$ had the highest productivity.

(b) Effect of incubation time and cell and $P D$ concentrations. As indicated in Fig. 5(A), the pyruvate production increased with an incubation time of up to $24 \mathrm{hr}$. The optimal cell concentration was 2.6 and $8 \mathrm{mg}$ (as dry weight) $/ \mathrm{ml}$ in 24 and $48 \mathrm{hr}$ reactions, respec- 


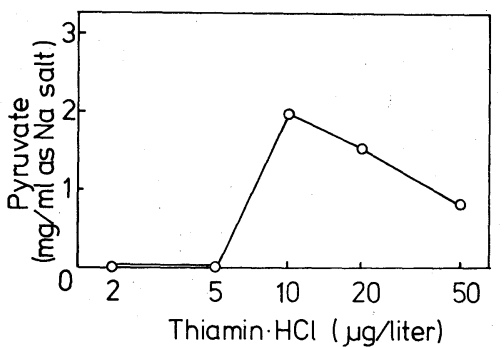

FIG. 4. Effect of Thiamin Concentration in the Culture Medium on the Pyruvate Production by Resting Cells of Strain 80-M.

The cultivation and reaction were carried out as described in Materials AND Methods except that the concentration of thiamin $\cdot \mathrm{HCl}$ in the culture medium was varied as indicated.

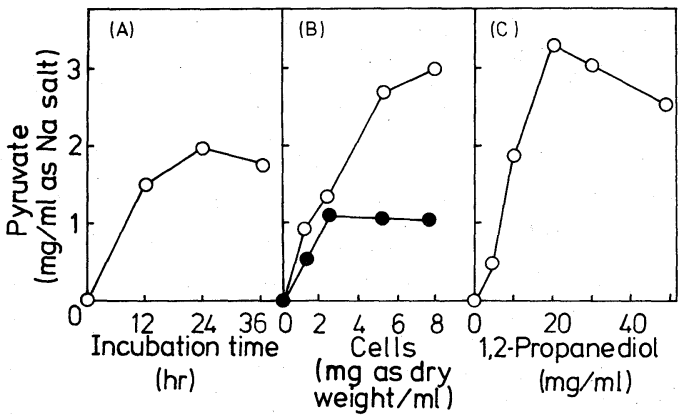

Fig. 5. Effect of Incubation Time and Cell and PD Concentrations on the Pyruvate Production by Resing Cells.

The reaction conditions were the same as in Fig. 4 except that the incubation time (A), cell concentration (B) and $\mathrm{PD}$ concentration $(\mathrm{C})$ were varied as indicated, respectively. In (B), incubation was carried out for 24 (O) and $48 \mathrm{hr}(\mathrm{O})$.

tively (Fig. 5(B)). The optimal PD concentration was $20 \mathrm{mg} / \mathrm{ml}$ (Fig. 5(C)).

(c) Effect of buffers and $\mathrm{pH}$. The effect of buffers with different $\mathrm{pH}$ values was examined. As shown in Fig. 6, the optimal $\mathrm{pH}$ for pyruvate production was around 8.5. In particular, a glycine- $\mathrm{NaOH}$ buffer of $\mathrm{pH} 8.5$ had the best effect on the pyruvate production $(10 \mathrm{mg} / \mathrm{ml}$ of pyruvate as sodium salt). It was confirmed that no pyruvate production occurred from glycine.

(d) Effect of aeration. The effect of aeration on the pyruvate production was tested by

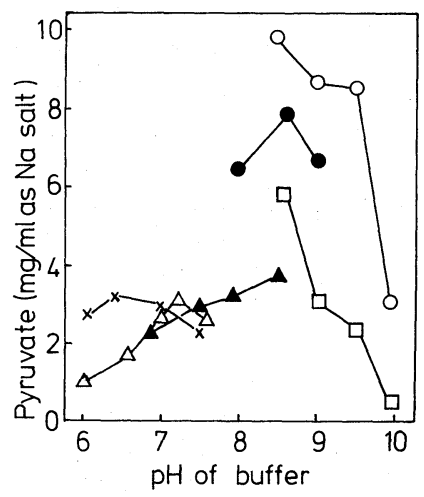

FIG. 6. Effect of Buffers and $\mathrm{pH}$ on the Pyruvate Production by Resting Cells.

The reaction was carried out at $28^{\circ} \mathrm{C}$ for $24 \mathrm{hr}$ in $5 \mathrm{ml}$ of the reaction mixture having the same composition as in Fig. 4 except that $3.6 \mathrm{mg}$ (as dry weight) $/ \mathrm{ml}$ of cells and $0.1 \mathrm{M}$ of the indicated buffer were used.

Buffer: $\times$, Tris-maleate buffer; $\triangle$, potassium phosphate buffer; $\Delta, \mathrm{KH}_{2} \mathrm{PO}_{4}-\mathrm{Na}_{2} \mathrm{~B}_{4} \mathrm{O}_{7}$ buffer; $\bigcirc$, Tris- $\mathrm{HCl}$ buffer; $\square, \mathrm{NH}_{4} \mathrm{OH}-\mathrm{NH}_{4} \mathrm{Cl}$ buffer; $\bigcirc$, glycine- $\mathrm{NaOH}$ buffer.

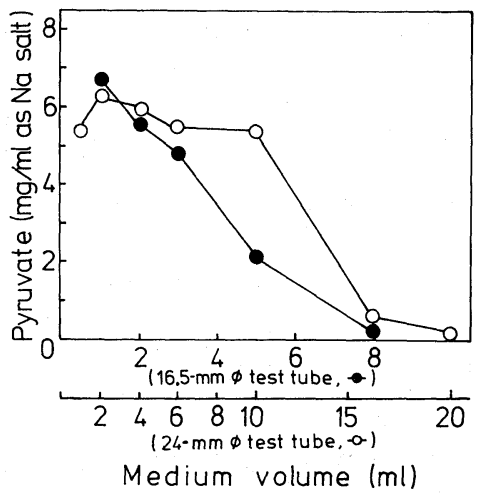

FIG. 7. Effect of Aeration on the Pyruvate Production by Resting Cells.

The reaction was carried out at $28^{\circ} \mathrm{C}$ for $24 \mathrm{hr}$ in a 16.5 $\mathrm{mm} \phi$ (O) or $24-\mathrm{mm} \phi$ test tube (O) containing the indicated volume of reaction mixture with the same composition as in Fig. 4 except that $0.1 \mathrm{M}$ glycine- $\mathrm{NaOH}$ buffer of $\mathrm{pH} 8.5$ and $3.9 \mathrm{mg}$ (as dry weight) $/ \mathrm{ml}$ of cells were used.

changing the volume of the reaction mixture. As shown in Fig. 7, vigorous aeration brought about the production of large amounts of pyruvate.

(e) Pyruvate production from $P D$ of resting cells grown on various carbon sources. The pyruvate production of resting cells grown on various carbon sources was examined to see 
Table V. Pyruvate Production from PD by Resting Cells Grown on VARIOUS CARBON SOURCES

The organism was cultivated in medium P-II containing Polypepton $(0.5 \%)$ and the indicated carbon source $(2 \%)$. Four mililiters of the reaction mixture, having the same composition as in Fig. 7, was incubated in a 24 $\mathrm{mm} \phi$ test tube at $28^{\circ} \mathrm{C}$ for $24 \mathrm{hr}$.

\begin{tabular}{ll}
\hline \multicolumn{1}{c}{ Cells grown on } & $\begin{array}{c}\text { Pyruvate } \\
(\mathrm{mg} / \mathrm{ml} \text { as Na salt })\end{array}$ \\
\hline None & 0.99 \\
1,2-Propanediol & 8.99 \\
1,3-Propanediol & 0.36 \\
Glucose & 0 \\
Ethanol & 0 \\
Glycerol & 0.99 \\
Sucrose & 0 \\
Fructose & 0 \\
\hline
\end{tabular}

whether the enzyme system of the pyruvate production from $\mathrm{PD}$ in the organism was inducibly or constitutively produced. Table V indicates that only the cells grown on PD showed a marked pyruvate productivity, while those grown on other carbon sources showed no or low productivity.

\section{DISCUSSION}

Interestingly, all the thiamin-requiring strains isolated from soil have been found to be pyruvate producers, as we expected, although the number of strains was small. Using strain $80-\mathrm{M}$, the present work also confirmed that thiamin plays an important role as a regulating factor for pyruvate production in both the growing cell and resting cell methods: the organism showed maximum pyruvate productivity when cultivated at $10 \mu \mathrm{g} / \mathrm{ml}$ of thiamin $\cdot \mathrm{HCl}$, while at higher concentrations of the vitamin, the productivity decreased significantly.

A method for pyruvate production using resting cells was demonstrated here for the first time. When the two methods, growing cell and resting cell, were compared, the maximum amount of pyruvate produced was larger using the growing cell method. However, the py- ruvate produced was more stable in case of the resting cell method. This may be because such substances as thiamin, amino acids and vitamin B6 compounds which are closely related to the pyruvate metabolism, were absent in the reaction mixtures in the resting cell system. The maximum amounts of pyruvate obtained using the growing cell and resting cell methods were 14.6 and $10.0 \mathrm{mg} / \mathrm{ml}$ as a sodium salt, respectively: the molar conversion ratios of $\mathrm{PD}$ to pyruvate were 50 and $34 \%$, respectively. These values are higher than those obtained by a growing cell method using Corynebacterium sp. $^{6)}$

Some papers ${ }^{10 \sim 14)}$ have appeared concerning the aerobic metabolism of PD in bacteria. These papers suggest the oxidation sequence of PD to pyruvate under strongly aerobic conditions as follows: PD $\rightarrow$ acetol (or lactaldehyde) $\rightarrow$ lactate $\rightarrow$ pyruvate. The enzyme, PD dehydrogenase, is known to be induced by PD. ${ }^{10,12,13)}$ The present work has demonstrated that a remarkable amount of pyruvate was produced from $\mathrm{PD}$ only by PDgrown cells, suggesting the existence of an inducible PD-dehydrogenating enzyme in strain $80-\mathrm{M}$ as well.

Acknowledgment. This work was supported in part by a Grant-in-Aid for Scientific Research from the Ministry of Education, Science and Culture of Japan.

\section{REFERENCES}

1) K. Kitahara and S. Fukui, Hakko Kogaku Kaishi, 29, 277, 326, 378 (1951).

2) K. Kitahara and S. Fukui, J. Gen. Appl. Microbiol., 1, 61 (1955).

3) Y. Sasaki and S. Takao, Nippon Nôgeikagaku Kaishi, 35, 313 (1961).

4) M. Shimamura and J. Yoshitake, Nippon Nôgeikagaku Kaishi, 44, 195, 283 (1970).

5) T. Saito, K. Udagawa and S. Abe, Nippon Nôgeikagaku Kaishi, 35, 313 (1961).

6) S. Takao and M. Tanida, Nippon Nôgeikagaku Kaishi, 51, 239 (1977).

7) T. E. Friedemann and G. E. Haugen, J. Biol. Chem., 147, 415 (1943).

8) G. Cerny, Eur. J. Appl. Microbiol., 3, 223 (1976).

9) "Bergey's Manual of Determinative Bacteriology," 8th Ed., Williams \& Wilkins Co., Baltimore, 1974.

10) Y. Tanaka, K. Fujii, A. Tanaka and S. Fukui, $J$. 
Ferment. Technol., 53, 354, 566 (1975).

11) O. Yagi and K. Yamada, Agric. Biol. Chem., 33, 1587 (1969).

12) N. Nishio, T. Kawagishi, R. Matsuno and T.
Kamikubo, Agric. Biol. Chem., 42, 1095 (1978).

13) T. Kawagishi, N. Nishio, R. Matsuno and T. Kamikubo, Agric. Biol. Chem., 44, 949 (1980).

4) A. Willetts, Biochim. Biophys. Acta, 588, 302 (1979). 